\title{
PENGARUH KECEPATAN REAKSI TANGAN, TERHADAP KEMAMPUAN FOREHAND TOPSPIN (Path Analysis Pada Atlet Tenis Meja UNSIKA Karawang 2016)
}

\author{
Rahedin Suwo \\ Universitas Muhammadiyah Buton \\ rahedinsuwo76@yahoo.com,082341186601
}

\begin{abstract}
ABSTRAK
Tujuan penelitian ini adalah untuk mendapatkan bukti empiris tentang pengaruh kecepatan reaksi tangan, terhadap kemampuan forehand topspin.. Penelitian ini dilakukan pada atlet tenis meja Unsika Karawang. Keseluruhan populasi berjumlah 56 orang, sampel dipilih dengan menggunakan teknik pertimbangan/ purposive sampling, dan sampel dalam penelitian ini berjumlah 30 atlet tenis meja. Hasil tes kecepatan reaksi tangan berpengaruh langsung terhadap kemampuan forehand tospin sebesar 0,0957. Penelitian ini menggunakan pendekatan kuantitatif asosiatif dengan teknik analyisis jalur. Hasil mengungkapkan bahwa; terdapat pengaruh positif secara langsung kecepatan reaksi tangan terhadap kemampuan forehand topspin.

Kata kunci; Kecepatan Reaksi Tangan, Forehand Topspin

\section{ABSTRACT}

The purpose of this study was to obtain empirical evidence about the effect of hand reaction, agility and self confidence in the ability forehand topspin. This study was conducted to table tennis athtletes of club Unsika University. Population amount 56 people, the sample taken with purposive sampling technique, the sample of the research is 30 man's table tennis athlete. Hipotesis testing the hand reaction has directly effect to ability forehand topspin 0,0957. This study uses a quantitative approach road Analyisis associative techniques. The results revealed that; Hand reaction has directly effect to ability forehand topspin.
\end{abstract}

Keywords; hand reaction, Forehand Topspin.

Dipublikasikan Oleh :

UPT Publikasi dan Pengelolaan Jurnal

Universitas Islam Kalimantan Muhammad Arsyad Al-Banjari Banjarmasin 


\section{PENDAHULUAN}

A. Latar Belakang

Olahraga merupakan suatu aktivitas gerak tubuh, mulai dari anggota bagian tubuh bagian atas dan bagian bawah. Dikatakan aktivitas karena memiliki tujuan pada akhirnya, yakni kualitas hidup yang meningkat, sehingga menjadikan tubuh menjadi sehat dan bugar. Aktivitas menyehatkan ini selain dijadikan aktivitas pengisi waktu luang, juga dapat dijadikan sarana untuk mengasah kemampuan diri dalam berolahraga atau wadah untuk menjadi atlet profesional atau olahraga prestasi.

Menurut Mikanda Rahmani (2014:1) olahraga prestasi merupakan aktivitas yang dilakukan dengan tujuan untuk untuk meraih kemenangan. Kemenangan ini menjadi kepuasan pribadi bagi atletnya kala dapat mencapai hasil yang maksimal. Pencapaian atau kemenangan ini ditandai dengan perolehan nilai atau medali tertinggi. Olahraga prestasi ini memiliki tingkat atau level, seperti level daerah yang dimulai dari PORDA, Kejurnas, PON, tingkat Asia hingga Olimpiade. Olimpiade merupaka pesta olahraga besar yang dilangsungkan tiap 4 tahun sekali dan diikuti banyak negara. Tentunya, pesta olahrga terbesar ini menjadi sebuah pesta olahraga yang paling bergengsi.

Perkembangan prestasi tenis meja di indonesia sudah semakin

pesat seiring dengan perkembangan zaman. Indonesia mampu meraih medali emas di berbagai kejuaraan internasional, diantaranya kejuaraan Asia dan kejuaraan Thailand terbuka tahun 2015. Sehingga dengan prestasi yang gemilang, salah satu atlet tenis meja putra terpilih sebagai nominasi diajang ITTF Award yang berlangsung tanggal 9 Desember 2015 tahun lalu di Portugal untuk kategori "Male Para Table Tennis Start of the Year (Bintang Tenis Meja Terbaik Difabel Putra). Di daerah-daerah telah banyak klub-klub dan pemusatan latihan yang telah digalakkan guna pencapaian prestasi, salah satunya seperti daerah DKI Jakarta. Tenis meja sangat berkembang pesat di DKI Jakarta yang ditandai dengan adanya pertandingan yang diselenggarakan oleh pemerintah daerah dari kelompok umur 6-12 tahun untuk pencarian bakat dan kelompok umum mulai divisi 7 (pemula) sampai divisi 1 (pemain nasional). Perkembangan ini juga ditandai dengan keberhasilan atlet putra dan putri tenis meja DKI Jakarta Lolos PON Bandung "Jawa Barat" tahun 2016.

Pencapaian prestasi terbaik tenis meja disamping didukung oleh sarana dan prasarana yang baik, juga masih banyak aspek-aspek latihan lain untuk mencapai prestasi tersebut. Menurut James Tangkudung (2012:42-43) untuk mencapai latihan tersebut ada empat aspek yang perlu diperhatikan oleh setiap guru pendidikan jasmani, pembina olahraga, dan pelatih olahraga yaitu : (1) Latihan fisik, (2) Latihan teknik, (3) Latihan taktik dan (4) Latihan mental. Pengetahuan dasar tentang latihan adalah langkah awal dalam menyusun program latihan yang optimal, dimana ada prinsip-prinsip yang akan efektif jika diaplikasikan.

Dalam permainan tenis meja selain membutuhkan koordinasi, ketangkasan dan energi agar bermain dengan baik, juga membutuhkan kebugaran tubuh dari lengan, dada, paha, sampai pinggul. Selain itu juga gerakan kaki harus lincah karena berperan penting dalam permainan ini. Hal terpenting dalam belajar permainan tenis meja adalah stroke (pukulan) atau teknik pukulan yang akan menjadi tipe permainan seseorang. Teknik pukulan tersebut dari waktu ke waktu harus mengalami perkembangan. Menurut Alex Kertamanah (2003:27) ada beberapa jenis stroke (pukulan) dalam permainan tenis meja, pada garis besarnya jenis-jenis pukulan itu antara lain: smash, block, drive, push, hit, servis, servis return, half volley, loop, side slip shot, drop shot, flick, long cut, short cut, dan loobing.

Kecepatan reaksi dibutuhkan untuk menambah kecepatan gerakan saat memukul bola. Keberhasilan topspin sangat ditentukan oleh

kemampuan memberikan gesekan permukaan karet bet pada bola. Jadi, kecepatan reaksi merupakan kemampuan seseorang dalam menjawab suatu rangsang dalam waktu yang sesingkat mungkin. (Sukadiyanto, 2011:116). Kecepatan reaksi dibedakan menjadi reaksi tunggal dan reaksi majemuk.

Unsur pendukung lain dalam melakukan pukulan topspin adalah adanya kelincahan dalam setiap pergerakan saat mendekati bola yang datang pada setiap sudut meja. Apabila seorang atlet memiliki kecepatan reaksi yang baik namun tidak didukung oleh pergerakan kelincahan kaki, maka akan sulit untuk menjangkau dan mengenai bola pada saat melakukan pukulan topspin.

Menguasai topspin tidaklah sulit, asalkan mau belajarn dan berlatih dengan tekun. Selain teknik dan kondisi fisik aspek psikologis yang juga sering mempengaruhi atlet adalah faktor percaya diri. tanpa memiliki penuh percaya diri, atlet tidak akan mencapai prestasi, karena ada saling hubungan antara mitivasi berprestasi dan percaya diri. percaya diri adalah seseorang sanggup dan mampu utnuk mencapai prestasi tertentu, apabila prestasinya sudah tinggi maka individu yang bersangkutan akan lebih percaya diri.

Dari pantauan dan pengamatan serta wawancara dengan pelatih yang dilakukan bahwa atlet tenis meja Club UNSIKA Karawang

Dipublikasikan Oleh :

UPT Publikasi dan Pengelolaan Jurnal

Universitas Islam Kalimantan Muhammad Arsyad Al-Banjari Banjarmasin 
masih banyak terdapat kekurangan dalam melakukan topspin dengan baik sewaktu bertanding. Sehingga para pemain sulit mematikan lawan untuk mendapatkan angka. Masih banyak terdapat kekurangan dalam melakukan pukulan topspin ini dapat dilihat ada banyak bola tidak mengenai bet dan jauh dari jangkauan serta tidak tepat sasaran sehingga menjadikan lawan mudah memperoleh poin/ angka.

Berdasarkan masalah di atas maka peneliti menduga penyebabnya antara lain adalah kurangnya, motivasi, percaya diri, konsentrasi, kecepatan reaksi tangan, kelincahan, koordinasi mata-tangan, kecepatan, daya tahan, mental, posisi pegangan bet, gizi dan lain sebagainya. Sehingga mendorong peneliti ingin melakukan penelitian berkaitan dengan pengaruh kecepatan reaksi, kelincahan dan percaya diri terhadap kemampuan forehand topspin atlet tenis meja

\section{METODE}

A. Tujuan Penelitian

Penelitian ini dilakukan dengan tujuan untuk mengetahui; Untuk mengetahui pengaruh langsung antara kecepatan reaksi tangan dan kemampuan forehand topspin.

B. Metode Penelitian

Penelitian ini menggunakan pendekatan kuantitatif dengan jenis penelitian kuantitatif asosiatif. Metode yang digunakan dalam penelitian ini adalah metode kausal dengan teknik Analisis Jalur. Teknik analisis jalur digunakan untuk menguji kesesuaian model, pengaruh langsung variabel, menganalisis hubungan antara variabel penelitian dan pengaruhnya.

Model konstelasi pengaruh antara variabel tersebut digambarkan sebagai berikut:

$\mathrm{X} 1$

Gambar 1.1 Konstalasi Model Penelitian

Keterangan;

$\mathrm{X} 1$ = Kecepatan Reaksi Tangan

$\mathrm{Y}=$ Kemampuan Forehand Topspin

C. Populasi dan Sampel

Populasi dalam penelitian ini adalah seluruh atlet tenis meja UNSIKA yang berjumlah 56 orang. Teknik pengambilan sampel menggunakan teknik purposive sampling, yakni dengan menggunakan pertimbangan tertentu, besar sampel dalam penelitian ini sebanyak 30 orang.

D. Teknik Pengumpulan Data

Teknik pengumpulan data adalah langkah penting dalam penelitian sehingga dalam penelitian ini digunakan teknik tes dan pengukuran. Tes adalah alat yang digunakan untuk mengukur beberapa peforma dan untuk mengumpulkan data. Pengukuran adalah skor kuantitatif yang berasal dari tes

\section{E. Teknik Analisis Data}

Teknik analisis data dalam penelitian ini menggunakan teknik analisis deskriptif dan analisis inferensial. Analisis deskriptif digunakan untuk melihat gambaran data dari masing-masing yang dinyatakan melalui mean, median, modus, distribusi frekuensi dan histogram. Selanjutnya dihitung besarnya pengaruh antara variabel eksogen terhadap endogen melalui analisis inferensial. Teknik analisis inferensial digunakan untuk menguji hipotesis menggunakan teknik analisis jalur (path analysis) dengan bantuan program SPSS yang didahului dengan uji persyaratan yaitu normalitas, uji signifikansi, dan linearitas regresi.

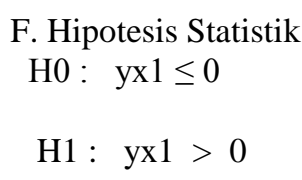




\section{HASIL DAN PEMBAHASAN}

A. Penyajian Persyaratan Analisis

Sebelum melakukan pengujian hipotesis, terlebih dahulu dilakukan penentuan dan pengujian koefisien jalur. Langkah-langkah penentuan pengujian pada analisis jalur

meliputi; (a) penentuan model structural tentang system yang dianalisis; (b) pengujian persyaratan pada path analysis yang meliputi; uji normalitas dan linearitas; (c) penentuan koefisien korelasi antara variabel eksogen dan endogen; (d)

Penentuan dan pengujian signifikansi koefisien jalur pada masing-masing variabel endogen dan eksogen; (e) penentuan besar pengaruh tidak langsung variabel X1 terhadap Y model struktural pengaruh kecepatan reaksi tangan terhadap kemampuan topspin forehand disajikan pada gambar di bawah ini:

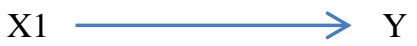

Gambar 1.3 Model Struktur Pengaruh Variabel Eksogen terhadap Variabel Endogen

Keterangan; Seluruh Koefisien

Korelasi Normal pada $\alpha=0,05$

Dalam tabel tersebut dapat dilihat bahwa seluruh koefisien korelasi antar-variabel bertanda positif. Disamping itu, seluruh nilai koefisien korelasi tersebut normal pada $\alpha=0,05$. Hal ini menunjukan bahwa terdapat hubungan positif antar variabel.

Keterangan:

$\mathrm{X} 1$ = Kecepatan Reaksi Tangan

$\mathrm{X} 2$ = Kelincahan

$\mathrm{X} 3$ = Percaya diri

$\mathrm{Y}=$ Kemapuan Forehand Topspin

Dengan demikian, secara keseluruhan hasil perhitungan uji normalitas galat dapat dilihat pada rangkuman tabel di bawah ini:

\begin{tabular}{|l|c|l|l|c|c|l|}
\hline \multirow{3}{*}{ No } & Galat Taksir an & \multirow{3}{*}{$\mathrm{N}$} & \multirow{2}{*}{ Lhitung } & \multicolumn{2}{|c|}{ Ltabel } & \multirow{2}{*}{ Keputusan } \\
& & & $\alpha=$ & $\alpha=$ & \\
& & & & 0,0 & 0,01 & \\
& & & & 5 & & \\
\hline
\end{tabular}

\begin{tabular}{|c|c|c|c|c|c|c|}
\hline 1 & $\begin{array}{c}\mathrm{Y} \text { atas } \\
\mathrm{X}_{1}\end{array}$ & 30 & $\begin{array}{l}0,0 \\
99\end{array}$ & $\begin{array}{l}0,1 \\
61\end{array}$ & 0,187 & $\begin{array}{c}\text { Berdistrib } \\
\text { usi } \\
\text { Normal }\end{array}$ \\
\hline 2 & $\begin{array}{c}\mathrm{Y} \text { atas } \\
\mathrm{X}_{2}\end{array}$ & 30 & $\begin{array}{l}0,1 \\
59\end{array}$ & $\begin{array}{l}0,1 \\
61\end{array}$ & 0,187 & $\begin{array}{c}\text { Berdistrib } \\
\text { usi } \\
\text { Normal }\end{array}$ \\
\hline 3 & $\begin{array}{c}\mathrm{Y} \text { atas } \\
\mathrm{X}_{3}\end{array}$ & 30 & $\begin{array}{l}0,1 \\
21\end{array}$ & $\begin{array}{l}0,1 \\
61\end{array}$ & 0,187 & $\begin{array}{c}\text { Berdistrib } \\
\text { usi } \\
\text { Normal }\end{array}$ \\
\hline 4 & $\mathrm{X}_{3}$ atas $\mathrm{X}_{1}$ & 30 & $\begin{array}{l}0,1 \\
60\end{array}$ & $\begin{array}{l}0,1 \\
61\end{array}$ & 0,187 & $\begin{array}{c}\text { Berdistrib } \\
\text { usi } \\
\text { Normal }\end{array}$ \\
\hline
\end{tabular}




\begin{tabular}{|c|c|c|c|c|c|c|}
\hline 5 & $\mathrm{X}$ atas $\mathrm{X}_{2}$ & & 0,1 & & & Berdistrib \\
& & 30 & 56 & 0,1 & 0,187 & usi \\
7 & & 61 & & Normal \\
\hline
\end{tabular}

B. Pengujian Hipotesis

Hasil perhitungan koefisien jalur digunakan untuk menguji hipotesis yang diajukan dan mengukur pengaruh, baik langsung maupun tidak langsung variabel eksogen terhadap variabel endogen. Penarikan kesimpulan hipotesis dilakukan melalui penghitungan nilai statistic $\mathrm{t}$ koefisien jalur, dengan ketentuan jika thitung > tabel, maka koefisien jalur normal dan sebaliknya jika thitung < ttabel, maka koefisien jalur tidak normal. Hasil pengujian terhadap hipotesis yang diajukan diperjelaskan sebagai berikut; dari perhitungan analisis jalur, pengaruh kecepatan reaksi tangan terhadap forehand topspin, nilai koefisien jalurnya sebesar 2,885 koefisien $\mathrm{t}$ hitung sebesar 8,475. Nilai dari koefisien $\mathrm{t}$ tabel untuk $\alpha=0,05$ sebesar 1,980 . Oleh karena nilai koefisien $\mathrm{t}$ hitung lebih besar dari pada nilai $\mathrm{t}$ tabel maka dengan demikian $\mathrm{H} 0$ di tolak dan $\mathrm{H} 1$ diterima yaitu bahwa kecepatan reaksi tangan berpengaruh langsung secara signifikan terhadap forehand topspin. Sehingga hipotesis yang menyatakan bahwa kecepatan reaksi tangan berpengaruh langsung positif terhadap forehand topspin dapat diterima.

\section{PENUTUP}

Hasil penelitian diatas diatas adalah maka dapat diajukan beberapa saran demi lebih baiknya kualitas anak didik kita: Bagi para Pembina dan pelatih tenis meja khusunya diharapkan selalu meningkatkan kemampuan forehand topspin dengan memperhatikan antropometri tubuh dan mengembangkan komponen fisik, terutama kecepatan reaksi tangan.

\section{REFERENSI}

Apta Mylsidayu, 2015. Febi Kurniawan Ilmu Kepelatihan Dasar. Bandung: Alfabeta,

Tangkudung James. 2012. Kepelatihan Olahraga "Pembinaan Prestasi Olahraga Edisi II". Jakarta: Cerdas Jaya

Sukadiyanto. 2011. Pengantar Teori dan Metode Melatih Fisik. Bandung: CV Lubuk Agung

Sutarmin. 2007. Terampil Berolahraga Tenis Meja. Surakarta: Era Intermedia

Ria Lumintuarso, 2013. Teori Kepelatihan Olahraga. Jakarta: LANKOR.

\section{Artikel Jurnal / Ensiklopedi}

Danny Plyler and Chad Seibert, 2009. The Ultimate Mixed Martial Arts Training Guide. Amerika: Betterway Sports.

Gross Bernd Ulrich dan Werner Schlager, 2011 Table Tennis Tips from a World Champion. Inggris: Meyer \& Meyer Sport, Ltd.

Katamanah Alex, 2003. Teknik \& Taktik Dasar Permainan Tenis Meja. Jakarta: Raja Grafindo Persada.

Rahmani Mikanda, 2014. Buku Super Lengkap Olahraga. Jakarta: Dunia Cerdas.

Richard McAfee, 2009. Table Tennis Steps to Success. United States : Human Kinetics. 